\title{
Analisis Kesalahan dalam Penulisan Karya Ilmiah Mahasiswa Jepang dalam Pembelajaran BIPA
}

\author{
Rahadiyan Duwi Nugroho, Cicilia Tantri Suryawati, \& Hendri Zuliastutik \\ Fakultas Sastra, Prodi Sastra Jepang, Universitas Dr. Soetomo \\ rahadiyan.duwi@unitomo.com
}

How to cite (in APA Style): Nugroho, R.D., \& Suryawati, T., Zuliastutik, H. (2018). Analisis kesalahan dalam penulisan karya ilmiah mahasiswa Jepang dalam pembelajaran BIPA. Jumal Pendidikan Bahasa dan Sastra, 18(2), doi:10.17509/bs_jpbsp.v18i2.15508

Article History: Received (30 july 2018); Revised (23 September 2018); Accepted (01 October 2018).

Journal homepage: http:// ejournal.upi.edu./index.php/BS_JPBSP

\begin{abstract}
Abstrak: Penelitian ini bertujuan untuk mengidentifikasi faktor kesalahan penulisan dan upaya mengidentifikasi penyelesaian kesalahan penulisan karya ilmiah pada mahasiswa Setsunan yang belajar bahasa Indonesia di Universitas Dr. Soetomo. Untuk mengkaji masalah penelitian, teori yang digunakan berkaitan dengan penggunaan bahasa baku dan benar, EYD dan analisis kesalahan sebagai teori utama. Metode yang digunakan yaitu deskriptif-kualitatif. Hasil penelitian menunjukkan bahawa faktor kesalahan penulisan terdapat pada kesalahan ejaan, tata bahasa dan sistematika. Kesalahan ejaan meliputi kesalahan penulisan huruf kapital, kecil dan miring. Kedua, kesalahan tata bahasa meliputi pemborosan penggunaan kata, penggunaan kalimat yang tidak tepat, tidak sampai sasaran dan tidak tuntas, serta penggunaan verba pasif di yang tertukar dengan fungsi awalan di sebagai kata depan. Ketiga, kesalahan sistematika penulisan meliputi tebal tipisnya huruf, koherensi, jarak antarsubbab dan ketidaktuntasan kalimat. Upaya penyelesaian kesalahan penulisan agar tidak terulang kembali dengan cara merealiasikan pembuatan modul penulisan karya ilmiah dengan bahasa yang sederhana dilengkapi dengan penjelasan sistematika, format dan substansi karya ilmiah.
\end{abstract}

Kata kunci: BIPA, ejaan, karya ilmiah, sistematika penulisan, tata bahasa

\section{Error Analysis in Writing Scientific Work by Japanese Students in BIPA Learning}

\begin{abstract}
This study aims to identify the factors of writing errors and efforts to identify errors in writing scientific papers on Setsunan students who study Indonesian at the University of Dr. Soetomo. To examine research problems, the theory used relates to the use of standard and correct language, EYD and error analysis as the main theories. The method used is descriptive-qualitative. The results of the study show that the writing error factors are in spelling errors, grammar and systematics. Spelling errors include capital letters, small and italics. Second, grammatical errors include wasteful use of words, use of sentences that are not right, not up to target and incomplete, and the use of passive verbs in which are confused with the prefix function as a preposition. Third, systematic writing errors include the thickness of letters, coherence, distance between letters and incompleteness of sentences. Efforts to resolve writing errors are not repeated again by realizing the creation of a module of scientific writing with a simple language equipped with a systematic explanation, format and substance of scientific work.

Keywords: BIPA, spelling, scientific work, systematic writing, gramma
\end{abstract}




\section{PENDAHULUAN}

Pergerakan manusia di era globalisasi dari satu negara ke negara lain sudah menjadi fenomena yang umum. Manusia berpindah dari negaranya ke negara lain dengan tujuan sebagai pekerja, pelajar, ataupun hanya sebagai wisatawan. Demikian juga dengan Indonesia. Negara Indonesia menjadi rujukan mereka bukan hanya untuk berwisata semata, melainkan menjadi rujukan untuk menempuh pendidikan maupun untuk bekerja.

Dalam rangka pencanangan Indonesia sebagai tempat belajar mahasiswa internasional, Kementerian Riset, Teknologi, dan Pendidikan Tinggi menargetkan jumlah mahasiswa asing di Indonesia pada 2019 mencapai 20.000 orang (Harian Surya, 24/8/2016). Semua mahasiswa asing tersebut diwajibkan untuk belajar bahasa Indonesia sebagai bahasa pengantar kehidupan sehari-hari. Peraturan kemenristekdikti tersebut menjadi salah satu alasan banyaknya perguruan tinggi di Indonesia yang membuka program BIPA

Universitas Dr. Soetomo (Unitomo) telah menjalin kerjasama dengan Universitas Setsunan Osaka Jepang (Setsunan) sejak tahun 2008. Sejak saat itu Setsunan telah mengirimkan mahasiswanya untuk belajar bahasa Indonesia di Unitomo sebanyak 33 mahasiswa. Mereka belajar di Unitomo selama 6 bulan atau 1 tahun. Selama belajar di Unitomo mahasiswa tersebut tidak hanya belajar bahasa Indonesia saja melainkan juga belajar budaya dan menulis karya ilmiah. Sesuai dengan rencana Unitomo untuk membuka kelas BIPA yang bukan hanya diperuntukkan bagi mahasiswa Setsunan saja, melainkan mahasiswa asing dari berbagai negara, maka mata kuliah penulisan karya ilmiah ini dapat menjadi ciri khas pembelajaran BIPA di Unitomo.

Penulisan karya ilmiah bagi mahasiswa mungkin tidak semudah menulis artikel bebas atau buku harian.
Karya ilmiah biasanya merupakan mata kuliah yang berkaitan dengan tugas akhir seperti skripsi atau tugas akhir ujian akhir semester seperti makalah. Di dalam karya ilmiah seperti makalah atau skripsi sangat memperhatikan sistematika penulisan, ejaan, pembacaan referensi atau literatur pustaka yang membutuhkan waktu yang relatif lama, serta harus memperhatikan jumlah halaman antartiap bab.

Bagi peneliti, penulisan karya ilmiah yang bersifat sistematis menyebabkan seorang penulis atau mahasiswa yang mengerjakannya, harus berpikir dua arah. Pertama, ia dituntut dapat menemukan tema penelitian yang cocok dengan minatnya. Kedua, ia dituntut secara tidak langsung mempelajari alur sistematika penjelasan karya ilmiah dari bagian awal, bagian isi maupun bagian akhir penelitian. Bila tidak memahami betul dan seksama model sistematika karya ilmiah, boleh jadi seorang penulis atau mahasiswa tersebut akan kesulitan dalam mengembangkan tema penelitiannya meski menarik sekalipun.

Hal yang paling mendasar dalam penulisan karya ilmiah sebelum memulai masuk ke ranah sistematika penulisan, seorang penulis patut memiliki ide atau gagasan yang menjadi minat penelitiannya. Bila tidak menemukan, ia akan terpaksa dalam mengerjakan makalah atau skripsinya yang akan berujung pada terputusnya ide atau ketidaktuntasan dalam membuat karya ilmiah. Bahkan dapat dikatakan ia akan gagal dalam tugas ini. Ide biasanya berkaitan dengan fenomena atau realita yang dialami seorang penulis. Fenomena tersebut disimpan erat dalam memorinya dan akhirnya dituangkan ke dalam karya ilmiah.

Bagi peneliti, sosok atau gambaran penelitian dapat diamati di dalam latar belakang penelitian. Oleh karena, subbab ini dapat peneliti anggap sebagai nyawa penelitian. Artinya, bila tidak ada latar belakang yang memiliki substansi yang berkualitas maka subbab-subbab 
selanjutnya tidak akan koheren atau berkesinambungan. Penulisan karya ilmiah dapat dikatakan sulit atau tidak mudah bukan hanya bagi mahasiswa sendiri, melainkan juga dialami oleh pembelajar asing, mahasiswa Setsunan yang belajar bahasa Indonesia di Unitomo.

Berdasarkan pengalaman yang telah dilakukan oleh pengajar, ada beberapa faktor yang mempengaruhi mereka sulit untuk memahami dan menulis karya ilmiah dalam waktu yang relatif singkat. Kendala pertama adalah karena perbedaan kemampuan bahasa Indonesia yang masih berada di level dasar atau belum menengah, membuat pengajar harus menyampaikan dengan bahasa Indonesia yang mudah, sehingga penjelasanpenjelasan yang rinci dalam penelitian akhirnya di-skip atau dikurangi. Kedua, dalam penelitian terkadang mahasiswa tidak langsung mengerti apa yang disampaikan oleh seorang dosen. Ketiga, penulisan ejaan dan kalimat bahasa Indonesia yang ditulis seperti bahasa ibunya, terkadang mempengaruhi artinya sehingga maknanya tidak mudah dipahami. Keempat, sering kali dari penelitian yang ditemukan, banyak mahasiswa yang tidak menggali kajian pustaka sebagai landasan dalam menganalisis. Beberapa hal inilah yang menjadi tantangan peneliti untuk meneliti faktor-faktor penyebab kesulitan mahasiswa Setsunan Jepang, angkatan ke13 semester gasal tahun akademik 2017/2018 serta mencari solusi agar mereka dapat menulis karya ilmiah dengan baik dan antusias.

Penelitian terdahulu tentang pembelajaran BIPA telah dilakukan oleh Azizah et al (2012). Pembahasan penelitian ini adalah deskripsi pembelajaran BIPA program CLS (Critical Language Scholarship) di Universitas Negeri Malang. Hasil penelitian ini adalah pembelajaran BIPA tahun 2012 memiliki spesifikasi yang memfokuskan pada pembentukan kemampuan berkomunikasi lisan. Secara khusus, penyelenggaraan pembelajaran terdiri dari tiga aspek, yakni aspek perencanaan, pelaksanaan dan problematik. Aspek perencanaan tergambar dari silabus dan tata kelola (sesuai dengan aspek instruksional pembelajaran BIPA). Kedua, aspek pelaksanaan terdata dari kegiatan pembelajaran yang dilakukan di kelas dan di luar kelas (tutorial dan kunjungan). Ketiga, aspek problematik terbagi atas perencanaan dan pelaksanaan. Dalam pelaksanaan pembelajaran terbagi menjadi dua, yaitu problem nonkebahasaan dan problem kebahasaan.

Selanjutnya, berkaitan dengan kondisi psikis, Sudaryanto (2016,p.3-5) mengemukakan bahwa menulis karya ilmiah terkadang dapat dipengaruhi oleh keadaan psikis, sehingga tidak jarang hambatan psikologis yang terendap di dalam jiwa dapat diidap oleh para guru, dosen atau mahasiswa dalam memulai membuat karya ilmiah. Hambatan pertama yang biasanya muncul adalah adanya anggapan bahwa tulisannya jelek, sehingga ada perasaan malu. Ada rasa tidak percaya diri di dalamnya. Hambatan kedua yang biasanya muncul adalah karena tidak ada minat, meski hanya menulis yang biasa-biasa saja, sehingga muncul keinginan tidak man menulis. Akibatnya, kebiasaan positif menulis tidak ada. Lalu, hambatan ketiga yang biasanya muncul adalah adanya anggapan menulis dengan baik tidak mampu. Jangan-jangan tulisannya tidak mudah dipahami karena tidak memperhatikan EYD. Akibat anggapan ini, persepsi negatif tidak dapat menulis akan tertanam dalam jiwa.

Hambatan di atas harus dikikis. Beliau menyatakan jangan malu! Kikislah rasa malu yang tidak pada tempatnya itu, karena ini adalah hal positif yang berefek bila ditekuni. Selanjutnya peningkatan kemauan harus ditempa dan ditempa, karena mewujudkan kemauan menulis karya ilmiah bukanlah hal yang memalukan tapi juga harus ada kemauan tekad. Terakhir, jangan pula membiasakan diri bersifat negatif menghakimi diri sendiri bahwa saya tidak mampu dan akhirnya menyerah. 
Selanjutnya, Sudaryanto (2016,p.10-11) menambahkan bahwa kinerja menulis hanya dapat dilaksanakan jika ada yang ditulis. Dalam konteks ilmiah, yang disebut "apa-apa" itu adalah ide, gagasan dan konsep. Penemuan ide, gagasan dan konsep dapat ditemukan lewat data. Jadi, data itu bahan dasar pertama yang tidak lain juga fakta-fakta, atau fenomen-fenomen yang hadir dalam pemahaman kita karena diberikan oleh alam, baik bersifat fisik (benda), biotik (berkembang hidup) maupun yang bersifat kreatif-kognitif (menciptakan kebaruan; seperti: bahasa, seni, masyarakat, ekonomi, dan sebagainya.)

Di samping itu, penemuan sebuah fenomen yang kemudian dapat diidekan menjadi konsep penelitian atau karya ilmiah, di samping adanya kemauan tekad, seorang penulis juga harus mempelajari kaidah kebahasaan bahasa karya ilmiah yang ditulis. Alwi, et al. (2003,p.15-16) menyatakan bahwa bahasa baku pada dasarnya dapat memperhubungkan semua penutur berbagai dialek bahasa. Dengan demikian, bahasa baku mempersatukan mereka menjadi satu masyarakat bahasa dan meningkatkan proses identifikasi penutur orang seorang dengan seluruh masyarakat itu. Selanjutnya, bahasa baku berfungsi sebagai kerangka acuan bagi pemakaian bahasa dengan adanya norma dan kaidah (yang dikodifikasi) yang jelas. Selanjutnya, Alwi, et al., (2003,p.20-21) menyatakan bahwa pemakaian bahasa yang mengikuti kaidah yang dibakukan atau yang dianggap baku disebut bahasa yang benar. Orang yang mahir menggunakan bahasanya sehingga maksud hatinya mencapai sasarannya, apa pun jenisnya itu, dianggap telah dapat berbahasa dengan efektif. Bahasanya membuahkan efek atau hasil karena serasi dengan peristiwa atau keadaan yang dihadapinya. Selanjutnya, bahasa yang baik adalah jenis pemakaian bahasa yang pemanfaatan ragamnya yang tepat dan serasi menurut golongan penutur. Artinya, selain baku adalah prinsip utama, perpaduan dengan penggunaan bahasa yang benar yang dapat mengenai dan dimengerti oleh sasaran juga diperlukan.

Bagi pembelajar BIPA, jika bahasa yang digunakan dalam menulis karya ilmiah belum sepenuhnya menguasai kaidah, maka bahasa yang digunakan walaupun dimengerti oleh dirinya sendiri, tapi belum tentu dapat dimengerti oleh penutur atau pembaca asli dari bahasa tersebut. Sering kali, apa yang dituliskan dapat mengacu pada penulisan kaidah bahasa ibunya yang tidak disesuaikan dengan bahasa sasarannya. Begitu juga dengan pemakaian konjungsi yang kadang tidak diperhatikan atau ditiadakan penggunaannya dalam merangkai kalimat. Dengan demikian, penguasaan ejaan, tata bahasa dan gaya bahasa wajib dimiliki oleh para pembelajar asing.

Penguasaan bahasa yang baik dan benar dalam berbahasa Indonesia, selain digunakan dalam ragam lisan, juga digunakan dalam ragam tulis. Pada Pusat Bahasa Kemendiknas Republik Indonesia (2012,p.5-6 \& 61), disebutkan bahwa pedoman umum ejaan bahasa Indonesia Yang Disempurnakan (EYD) meliputi: pemakaian huruf, penulisan kata, pemakaian tanda baca dan penulisan unsur serapan. Berikut uraiannya.

1. Pemakaian huruf meliputi: huruf abjad, vokal, konsonan, diftong, gabungan huruf konsonan, pemenggalan kata, huruf kapital, huruf miring dan huruf tebal.

2. Penulisan kata meliputi: kata dasar, kata turunan, bentuk ulang, gabungan kata, suku kata, kata depan, partikel, singkatan dan akronim, angka dan bilangan serta kata ganti ku-, kau-, -ku, -mu, dan -nya.

3. Pemakaian tanda baca meliputi: tanda titik (.), tanda koma (,), titik dua (:), hubung (-), tanya (?), seru (!), petik (“"), tanda miring.

4. Penulisan unsur serapan menyerap dari bahasa daerah maupun bahasa asing seperti Sansekerta, Arab, Portugis, Belanda, Cina dan Inggris.

Keraf (2010,p.21-22) menyatakan bahwa kata merupakan suatu unit dalam 
bahasa yang memiliki stabilitas intern dan mobilitas posisional, yang berarti ia memiliki komposisi tertentu dan secara relatif memiliki distribusi yang bebas. Distribusi yang bebas misalnya dapat dilihat dalam kalimat: Saya memukul anjing itu; anjing itu kupukul; kupukul anjing itu. Hal yang paling utama dari rangkaian kata-kata yang dapat berdistribusi bebas sesuai dengan tataran sintaksis adalah adanya pengertian tersirat di balik kata yang digunakan itu. Pengertian tersirat dalam sebuah kata berarti kata itu mengandung makna dan juga ide.

Selanjutnya, bila seseorang menyadari bahwa kata merupakan alat penyalur ide atau gagasan, seyogyanya seseorang yang mempelajari bahasa harus menguasai kosakata. Semakin banyak kata yang dikuasai seseorang, semakin banyak pula ide atau gagasan yang dikuasainya dan sanggup untuk diungkapkannya. Mereka yang luas kosakatanya, dapat dengan mudah berkomunikasi dengan orang lain.

Di samping penguasaan terhadap bahasa dan ejaan, gaya atau dalam retorika dikenal dengan sebutan style (Keraf, 2010,p.112-113) memegang peranan penting dalam penulisan karya ilmiah. Bila dilihat dari segi bahasa, gaya bahasa adalah cara menggunakan bahasa. Gaya bahasa memungkinkan kita dapat menilai pribadi, watak dan kemampuan seseorang yang menggunakan bahasa tersebut. Gaya bahasa yang baik harus mengandung tiga unsur yaitu, kejujuran, sopan-santun dan menarik. Semakin baik gaya bahasanya, semakin baik pula penilaian orang terhadapnya. Keahlian menggunakan alat ini akan mempengaruhi jelas tidaknya tulisan. Persoalan gaya bahasa meliputi semua hierarki kebahasaan, seperti: pilihan kata secara individual, frase, klausa, kalimat dan bahkan mencakup wacana secara keseluruhan.

Bagi mahasiswa asing kesalahan dalam mengungkapkan ide dalam penulisan karya ilmiah dapat dikatakan wajar. Corder dalam Siagian (2017) menyatakan bahwa ada tiga istilah dalam pembatasan kesalahan berbahasa, yaitu 1) lapses: kesalahan berbahasa akibat penutur beralih cara untuk menyatakan sesuatu sebelum tuturan selesai dinyatakan selengkapnya (slip of the tongue untuk lisan atau slip of the pen untuk tulisan); 2) error: kesalahan berbahasa akibat penutur melanggar kaidah atau aturan tata bahasa (breaches of code); dan mistake: kesalahan berbahasa akibat penutur tidak tepat dalam memilih kata atau ungkapan untuk situasi tertentu. Salah satu penanda kesalahan tersebut dapat dianalisis dari kesalahan berbahasa tulis, Lan dalam Fatimah (menggunakan klasifikasi kategori kesalahan sebagai berikut. a) kesalahan morfologi yaitu kesalahan pada pembentukan kata, khususnya kosakata yang mempunyai morfem-morfem terikat. Kesalahan ini meliputi kesalahan pada konjugasi kata kerja, deklinasi kata benda, kata sifat, dan kata ganti, b) kesalahan sintaksis yaitu kesalahan yang menyangkut struktur kalimat. Kesalahan ini meliputi kesalahan pada penempatan kata, reksi (penguasaan sebuah kata terhadap kata lainnya), dan kongruensi (penyesuaian subjek dengan kata kerja dalam sebuah kalimat), c) Kesalahan leksikon yaitu kesalahan dalam memilih dan menggunakan kosakata dalam sebuah kalimat.

\section{METODE}

Metode dalam penelitian ini adalah metode penelitian deskriptif-kualitatif. Di dalam penelitian bahasa, metode penelitian deskriptif cenderung digunakan dalam penelitian kualitatif, terutama dalam mengumpulkan data kemudian menggambarkan data secara ilmiah. Lebih rinci, Djajasudarma (2010,p. 9) berpendapat bahwa metode penelitian deskriptif adalah metode yang bertujuan membuat deskripsi; membuat gambaran, lukisan secara sistematis, faktual dan akurat mengenai data, sifat-sifat serta hubungan fenomenafenomena yang diteliti. Selanjutnya, Moleong (2017,p. 2-7) menambahkan bahwa penelitian kualitatif bersifat natural, karena untuk mengkaji dan mengungkap fenomena subjek yang diteliti diperlukan sebuah proses deskripsi alami dan terinci lewat uraian kata atau kalimat. Dengan 
demikian, hasil dari proses pengungkapan karakteristik atau ciri dari subjek yang diteliti akan jauh lebih akurat dan objektif.

Sumber data penelitian ini adalah hasil karya ilmiah mahasiswa Setsunan angkatan angkatan ke-13 semester gasal tahun akademik 2017/2018. Data dalam penelitian ini adalah portofolio atau kumpulan-kumpulan lembar pekerjaan mata kuliah Penulisan Karya Ilmiah 1, yakni tugas UTS dan tugas UAS. Data penelitian ini dikumpulkan dengan melalui tahapantahapan di antaranya: (1) pengumpulan tugas-tugas mahasiswa Setsunan dari praUTS \& tugas UTS sampai tugas pra-UAS \& tugas UAS. Setiap tugas yang dikumpulkan akan diketahui kemajuannya; (2) penjaringan faktor-faktor kesulitan penulisan seperti: ejaan, tata bahasa, kekoherensian dan format penulisan, dan; (3) Pengklasifikasian faktor-faktor tersebut agar siap dianalisis. Sebagai gambaran data kesalahan penulisan karya ilmiah mahasiswa Setsunan divariabelkan menjadi 3 yaitu, variabel ejaan, tata bahasa dan sistematika penulisan.

Selanjutnya, teknik analisis data adalah merupakan suatu upaya untuk menemukan konsep atau temuan baru penelitian dengan cara mengobservasi dan menguraikan karakteristik data yang dilakukan secara sistematis atau sesuai urutan pola melalui suatu proses (Moleong, 2001: 103). Dalam hal ini teknik analisis data penelitian ini melalui proses: (1)analisis jenis dan bentuk data dalam setiap faktor kesulitan penulisan yang meliputi: ejaan, tata bahasa, kekoherensian dan format penulisan; (2) analisis solusi dalam setiap faktor kesulitan yang telah dilakukan mahasiswa Setsunan dalam menulis karya ilmiah, dan; (3) penyimpulan hasil penelitian.

\section{HASIL DAN PEMBAHASAN}

1. Kesalahan Penulisan Huruf Kapital, Kecil dan Miring

Pada penulisan huruf, kesalahan penulisan terdapat pada penulisan huruf kapital, huruf kecil dan huruf miring. Temuan data bersifat variatif, baik UTS maupun UAS hingga keduanya terulang kembali di UTS dan UAS. Berikut adalah uraian data kesalahan penulisan huruf yang dihimpun dalam tabel beserta analisisnya.

Tabel A.1 Kesalahan Penulisan Huruf Kapital, Kecil dan Miring

\begin{tabular}{|c|c|c|c|}
\hline No. & Bentuk-Bentuk Kesalahan & UTS & UAS \\
\hline \multirow[t]{6}{*}{1} & Penulisan huruf kapital. & & \\
\hline & (1) Bukan nama diri geografi. & $\sqrt{ }$ & \\
\hline & (2) Bukan termasuk subbab, melainkan pemerian. & $\sqrt{ }$ & $\sqrt{ }$ \\
\hline & (3) Setelah tanda koma (,). & & $\sqrt{ }$ \\
\hline & (4) Awalan kata depan. & & $\sqrt{ }$ \\
\hline & (5) Awal kata yang bukan istilah yang khusus. & & $\sqrt{ }$ \\
\hline \multirow[t]{5}{*}{2} & Penulisan huruf kecil & & \\
\hline & (1) Awalan kata nama agama dan gelar kenabian. & $\sqrt{ }$ & \\
\hline & (2) Awalan kata subbab. & $\sqrt{ }$ & \\
\hline & (3) Awalan kata yang terletak di awal kalimat. & $\sqrt{ }$ & $\sqrt{ }$ \\
\hline & (4) Penulisan judul di halaman sampul. & $\sqrt{ }$ & $\sqrt{ }$ \\
\hline \multirow[t]{2}{*}{3} & Penulisan kata asing. & & \\
\hline & (1) Tidak menggunakan huruf miring. & & $\sqrt{ }$ \\
\hline
\end{tabular}

\section{a. Kesalahan Penulisan Huruf Kapital}

Pada data ke-1, kesalahan awalan penulisan kosakata asli Jepang yang bukan nama diri geografi menggunakan huruf kapital dan tidak dimiringkan. Kosakata yang dimaksud terdapat dalam penulisan 
latar belakang yang berbunyi: ...dengan kebiasaan masuk ke Yokusou.... Padahal dalam bahasa Indonesia, kosakata yokusou memiliki arti bak mandi dan tidak ada kaitannya dengan nama diri suatu wilayah atau daerah. Kemungkinan pada saat menulis, mahasiswa yang mengangkat judul "Perbedaan Mandi antara Jepang dan Indonesia" lupa mengecek kembali istilah asing yang ditulisnya dan belum memahami bahwa istilah asing yang bukan nama diri suatu daerah/wilayah tidak perlu ditulis dengan huruf kapital di awal katanya. Kesalahan tersebut terdapat pada tugas UTS dan tidak terulang di tugas UAS.

Pada data ke-2, kesalahan awalan penulisan kosakata yang bukan subbab melainkan kosakata yang diperikan/dirincikan menggunakan huruf kapital. Kosakata yang dimaksud terdapat pada kata angket dalam subbab metode dan teknik penelitian di bab I yang secara rinci berbunyi: 1. Menyebarlukan Angket, 2. Membagi Angket. Seharusnya, penulisan huruf kapital [A] tetap menggunakan huruf kecil karena bukan penulisan subbab yang tanpa menggunakan tanda titik (.). Kemungkinan pada saat menulis, mahasiswa yang mengangkat judul "Tentang Sepeda Motor di Surabaya" menganggap bahwa unsur kosakata yang dirincikan juga perlu ditulis dengan huruf kapital pada awal penulisan katanya. Kesalahan tersebut terdapat pada tugas UTS dan terulang di tugas UAS.

Pada data ke-3, kesalahan awalan penulisan kosakata setelah tanda koma (,) menggunakan huruf kapital. Kosakata yang dimaksud terdapat pada kata gunakanlah dalam bab II landasan teori. Rupanya peneliti mengutip artikel tentang peraturan pengguna sepeda motor. Kalimat tersebut berbunyi: ...kenakan helm batok, Gunakanlah belm SNI. Seharusnya, penulisan huruf kapital [G] tetap menggunakan huruf kecil karena masih bagian dari klausa yang pertama. Kemungkinan pada saat menulis, mahasiswa tersebut mengkopi apa adanya dari artikel orang lain dan tidak teliti membetulkan ejaan yang dikutip. Kesalahan tersebut baru muncul di UAS. Selanjutnya, pada data ke-4, kesalahan awalan penulisan kosakata terjadi pada kata depan pada yang menggunakan huruf kapital. Kosakata yang dimaksud terdapat pada bab II landasan teori yang juga membahas tentang peraturan pengguna sepeda motor. Kutipan kalimat tersebut berbunyi: ...tersebut $\boldsymbol{P} a d a$ persimpangan... Seharusnya, penulisan awalan huruf [P] pada kata depan pada tetap menggunakan huruf kecil. Kemungkinan pada saat menulis, mahasiswa tersebut mengkopi apa adanya dari artikel orang lain dan juga tidak teliti membetulkan ejaan yang dikutip. Kesalahan tersebut baru muncul di UAS.

Terakhir, pada data ke-5, kesalahan awalan penulisan kosakata puasa yang bukan sebagai istilah khusus menggunakan huruf kapital. Kosakata yang dimaksud ditemukan dalam bab III (pembahasan) yang berbunyi: Jadi Puasa juga acara yang terkenal di Surabaya. Meski merupakan kosakata yang berkaitan dengan ibadah wajib umat muslim, seharusnya awalan kosakata puasa tetap ditulis menggunakan huruf kecil, karena bukan sebuah istilah yang asing lagi bagi pemeluknya. Kemungkinan pada saat menulis, mahasiswa yang mengangkat judul "Tentang Kebiasaan Orang Islam di Surabaya" kurang memahami bahwa istilah keagamaan yang bukan istilah khusus dan dikhususkan tidak perlu ditulis dengan huruf kapital di awal katanya. Kesalahan tersebut terdapat pada tugas UAS.

\section{b. Kesalahan Penulisan Huruf Kecil}

Pada data ke-1, kesalahan awalan penulisan kosakata agama dan gelar kenabian menggunakan huruf kecil. Kosakata tersebut ditemukan dalam bab latar belakang yang berbunyi: ...tentang agama kristen, kedua Karena islam paling.... Padahal, setiap awalan kosakata untuk nama agama wajib menggunakan huruf kapital. Penulisan ini ditemukan dalam tugas UTS, namun sudah tidak ditemukan lagi di tugas UAS. Hal ini disebabkan penulis sudah mengetahui penulisan yang benar tentang nama agama sebagai bentuk penghormatan 
kepada pemeluknya, sehingga setiap kali menulis nama agama apapun, penulis telah menggunakan huruf kapital di awal kata.

Sebaliknya, untuk penulisan gelar kenabian, penulis yang menulis judul penelitiannya dengan "Tentang Kebiasaan Orang Islam di Surabaya", menulis huruf kecil dalam awalan katanya. Data ini ditemukan di bab III (pembahasan) dalam penggalan kalimat berikut: ...Nabi Mubammad shallallabu 'alaibi wasallam. Tugas ini ditemukan dalam tugas pra-uas. Tim peneliti menduga bahwa penulis belum mengetahui bahwa selain gelar kenegaraan, gelar kenabian juga harus ditulis dengan huruf kapital di setiap awalan katanya sebagai bentuk penghormatan. Apalagi, gelar tersebut melekat dengan nama Nabi.

Pada data ke-2, kesalahan awalan penulisan kosakata urutan kedua subbab menggunakan huruf kecil. Kosakata tersebut ditemukan dalam kata masalab pada subbab B. Rumusan masalah dan kata penelitian pada subbab C. Tujuan penelitan. Dua hal ini hanya terdapat pada tugas UTS. Tim peneliti menduga, kesalahan penulisan huruf kecil pada kedua subbab yang ada di bab I tersebut karena mereka hanya menerima format yang dosen pengajar berikan tanpa pernah bertanya saat diterangkan kenapa harus menggunakan huruf kapital untuk awalan kosakata yang ada di setiap subbab, serta tidak terlalu memahaminya. Mereka fokus pada substansi penelitian masing-masing daripada formatnya. Padahal, setiap awalan kosakata yang ditulis di subbab dan tidak diakhiri dengan pemarkah titik (.), tidak ditulis menggunakan huruf kecil melainkan huruf kapital.

Selanjutnya, pada data ke-3 dan ke4, kesalahan terjadi dari tugas UTS hingga menjelang UAS. Kesalahan tersebut adalah penggunaan huruf kecil sebagai awalan kata yang mengawali sebuah kalimat. Kata tersebut adalah kata selanjutnya yang ditemukan di bab I (latar belakang) dengan penggalan kalimat yang berbunyi: selanjutnya tekbnik penelitian ini... Selanjutnya, kesalahan ke-4 terjadi pada penulisan judul di cover atau halaman sampul dengan judul: Tentang Sepeda Motor di Surabaya. Seharusnya, dalam cover judul tersebut menjadi huruf kapital semua seperti TENTANG SEPEDA MOTOR DI SURABAYA. Tim peneliti menduga kesalahan yang terulang dalam data ke-3 dan ke-4 hingga menjelang UAS disebabkan karena mahasiswa tidak merevisi catatan dari dosen yang mengoreksi pekerjaannya. Akan tetapi, saat UAS, kesalahan ini sudah tidak ditemukan.

\section{c. Kesalahan Penulisan Kata Asing}

Kesalahan penulisan kata asing dengan menggunakan huruf tegak bukan miring juga ditemukan dalam keempat penelitian mahasiswa Setsunan. Semuanya hampir ditemukan di tugas menjelang UAS. Kosakata tersebut antara lain: touring dan sepatu boots pada penelitian yang berjudul "Tentang Sepeda Motor di Surabaya", udeng dan baju Pesaan dalam penelitian yang berjudul "Pakaian Tradisional Jawa Timur". Ketiga, kosakata serapan dari bahasa Arab seperti mahabbah (kecintaan), ibadah lisaniyah qalbiyah (lisan dan hati) pada penelitian yang berjudul "Tentang Kebiasaan Orang Islam di Surabaya". Keempat, kata Yokusou (bak mandi) pada penelitian yang berjudul "Perbedaan Mandi antara Orang Jepang dan Indonesia". Tim peneliti menduga, kesalahan penulisan kosakata asing dengan menggunakan huruf tegak bukan miring, karena kurang kebiasaan menulis huruf latin dalam membuat sakubun 'karangan', melainkan dengan aksara kana dan kanji. Sedangkan dalam penggunaan huruf latin, baik bahasa Indonesia atau bahasa Inggris pun, setiap kosakata asing yang masuk ke dalam bahasa tersebut harus dimiringkan penulisannya.

Berdasarkan analisis tersebut, tim peneliti menyimpulkan bahwa untuk memahami cara dan situasi penulisan huruf kapital, huruf kecil dan kata bercetak miring dengan benar, maka wajib bagi penulis asing untuk sering membaca buku EYD sebelum mengerjakan tugas pembuatan karya ilmiah. 
Atau, ia dapat menjadikan buku tersebut sebagai pendamping dalam mengerjakan tugas pembuatan karya ilmiah. Di samping itu, apabila dalam penulisan tugas, terdapat kesalahan penulisan huruf kapital yang ditandai dengan huruf merah, wajib bagi pembelajar untuk segera berkonsultasi kepada dosen pengajar yang bersangkutan agar tidak segera lupa.

\section{Penulisan Kata}

Pada penulisan kata, kesalahan penulisan terdapat 4 kasus. Pertama, hilangnya huruf vokal dan konsonan, serta gabungan vokal-konsonan. Kedua, penyisipan huruf yang salah. Ketiga, kemunculan kosakata asing karena pengaruh grammar setting di komputer dan keempat adanya kekeliruan dalam membedakan awalan di sebagai kata depan dan di sebagai verba pasif. Temuan data terulang di UAS meski mereka sudah mendapatkan catatan di UTS. Berikut adalah uraian data kesalahan penulisan kata yang dihimpun dalam tabel beserta analisisnya.

Tabel A.2 Kesalahan Penulisan Kata

\begin{tabular}{clcc}
\hline No. & \multicolumn{1}{c}{ Bentuk-Bentuk Kesalahan } & UTS & UAS \\
\hline \multirow{2}{*}{1} & Hilangnya vokal dan konsonan. & & \\
\cline { 2 - 4 } & (1) Vokal [a], [i], [u], [e] & $\sqrt{ }$ & $\sqrt{ }$ \\
\cline { 2 - 4 } & (2) Konsonan [g] [h], [n] & $\sqrt{ }$ & $\sqrt{ }$ \\
\cline { 2 - 4 } & Hilangnya gabungan vokal dan konsonan & $\sqrt{ }$ & $\sqrt{ }$ \\
\hline 2 & Penyisipan huruf yang salah dan tidak perlu. & $\sqrt{ }$ & $\sqrt{ }$ \\
\hline 3 & Kosakata asing muncul karena pengaruh grammar. & $\sqrt{ }$ & $\sqrt{ }$ \\
\hline 4 & Penggunaan kata depan dan verba pasif. & $\sqrt{ }$ & \\
\hline
\end{tabular}

\section{a. Hilangnya Vokal dan Konsonan}

Kesalahan penulisan kata terjadi dengan hilangnya vokal dan konsonan. Data pertama hingga data ketiga adalah hilangnya vokal [a] di antara sebuah kata yang ditulis. Data ke-1 vokal [a] hilang antara huruf konsonan $[\mathrm{p}]$ dan $[\mathrm{t}]$ pada kata dapat yang ditemukan dalam kalimat: Saya dpat naik sepeda motor... Data ke-2 vokal [a] hilang antara huruf konsonan [g] dan [1] pada kata mengalami yang ditemukan dalam kalimat: saya menglami cedera serius. Data ke-3 vokal [a] hilang antara huruf konsonan [n] dan [s] pada kata kepanasan yang ditemukan dalam kalimat: ...mereka tidak kepansan? Selanjutnya, data keempat hingga data ketujuh adalah hilangnya vokal [u] di antara huruf konsonan [j] dan vokal [a] pada kata tujuan dalam data: C. Tujan Penelitian. Kelima, hilangnya vokal [i] di antara huruf konsonan [ $\mathrm{t}$ ] dan vokal [a] pada kata penelition dalam data: C. Tujuan Penelitan. Keenam, hilangnya vokal [e] di antara huruf konsonan $[\mathrm{s}]$ dan $[\mathrm{k}]$ pada kata sekolah dalam data: bus untuk pergi skolah.
Ketujuh, hilangnya vokal [e] untuk kata mengetahui dalam data: untuk lebih mengtahui pakaian.... Tim peneliti menduga, banyaknya vokal sebagai huruf sisipan yang membantu bunyi sebuah kata dapat menghilang, karena mereka menganggap huruf hidup atau vokal yang diapit oleh konsonan tertentu seperti [g], [l], $[\mathrm{n}],[\mathrm{s}],[\mathrm{j}],[\mathrm{t}],[\mathrm{s}],[\mathrm{k}]$ dapat dibuat seperti tidak bersuara saat membacanya.

Selanjutnya, hilangnya konsonan terjadi pada konsonan [g] pada kata sehingga dalam data: ...agama Islam, sehinga saya ingin.... Kedua, konsonan [h] pada kata ilmiah dalam data: KARYA ILMIA I. ketiga, hilangnya konsonan [n] pada kata kencang, menghindar, dengan dan tentang dalam data: ... dari hujan dan angin kecang, ...tidak dapat menghidar dari..., ...tertarik degan agama..., Menurut Undang-undang tetang sepeda motor... Keempat, ditambah dengan hilangnya vokal [a] dan konsonan [s] pada kata menyebarluaskan dengan data: Menyebarlukan Angket. Tim peneliti menduga, hilangnya konsonan $[\mathrm{g}]$ 
disebabkan oleh ketidakseringan penulis dalam menulis bunyi konsonan ganda huruf latin dengan mengulang kembali huruf latin yang mendahuluinya. Dalam aksara kana mereka terbiasa menulis bunyi konsonan ganda dengan tanda つ(tsu kecil). Selanjutnya, hilangnya konsonan [h] pada kata ilmiah juga tim peneliti anggap dapat terjadi karena ketidakseringan penulis mendengar bunyi konsonan [h] sebagai bunyi yang harus diwujudkan untuk mengakhiri sebuah kata. Terakhir, hilangnya konsonan [n] yang tersisip di tengah-tengah kata hindar, tentang, dengan, dan kencang dapat tim peneliti anggap karena penulis belum terbiasa menyisipkan konsonan tunggal yang sebelumnya diawali dengan diakhiri dengan suku kata terbuka (konsonan-vokal).

\section{b. Penyisipan Huruf yang Salah}

Penyisipan huruf yang salah dan tidak perlu dapat menihilkan arti kosakata yang ditulis, misalnya kata setiap menjadi setaip, terakbir menjadi teriakbir, dan mereka menjadi merelka, program menjadi prpgram dan tentang menjadi tentaang. Peneliti menduga, bahwa penulis tidak teliti dan tidak berusaha mengecek kembali kosakata yang ditulisnya dalam tugas karya ilmiah. Selain itu, ketidaktelitian juga terjadi pada penulisan suku kata lu menjadi huruf biragana ru (る) pada kata pendabuluan yang menjadi pendaburuan. Ternyata, pengaruh bahasa Ibu dengan kebiasaan memakai huruf hiragana juga mempengaruhi wujud tulisan latin penulis. Apalagi, dalam bahasa Jepang tidak ada huruf bersuku kata lu melainkan $r u$, sehingga penulis mungkin lupa kemudian menulisnya dengan kata pendaburuan.

Terakhir, penyisipan huruf yang tidak perlu juga dapat menihilkan arti kosakata. Misalnya, kata sumuanya yang seharusnya ditulis semuanya, helum yang seharusnya belm, dan pusutaka yang seharusnya ditulis pustaka. Tim peneliti menduga bahwa pengaruh suku kata terbuka dalam setiap huruf Jepang mampu mempengaruhi wujud tulisan latin penulis.
Hal lainnya yakni penulisan nama penulis yang seharusnya Masruri menjadi Masururi. Artinya, konsonan [s] yang bertemu dengan konsonan $[\mathrm{r}]$ adalah kedua huruf mati, sehingga agak sulit diucapkan. Oleh karena itu, penulis kemudian secara tidak sengaja menambahkan huruf hidup berupa vokal $[\mathrm{u}]$, sehingga menjadi suku kata terbuka [su] dan mudah dibaca.

\section{c. Kosakata Asing Muncul karena Pengaruh Grammar}

Kesalahan penulisan kata yang lain yakni kemunculan kosakata asing karena pengaruh grammar yang ter-setting bahasa Inggris di laptop salah satu mahasiswa. Akibatnya, ada beberapa kosakata yang seharusnya sudah tertulis tepat menggunakan bahasa Indonesia berubah seketika menjadi bahasa Inggris. Misalnya, kata dan menjadi and, social menjadi social, religius menjadi religious, servis menjadi service dan Universitas menjadi Universities. Walau sedari awal penulis mengetahui hal tersebut, nampaknya kurang mengindahkan dan serius untuk menyeting laptopnya agar berterima menggunakan bahasa Indonesia.

\section{d. Penggunaan Kata Depan dan Verba Pasif Awalan Di}

Kesalahan penulisan kata yang terakhir yaitu terbaliknya penggunaan kata di sebagai kata depan dan di sebagai unsur verba pasif. Hal ini ditemukan pada data kalimat yang berbunyi: Metode yang di gunakan dalam penelitian..., dan ...samping dan dibelakang kendaraan.... Tim peneliti menduga, adaya kesalahan kecil di atas dapat disebabkan oleh 2 hal. Pertama, ketidaksengajaan penulis ketika mengetik. Kedua, faktor ketidakpahaman penulis dalam membedakan kapan kata di dipisah penulisannya, dan kapan digabung penulisannya saat pelajaran Bahasa Indonesia berlangsung.

Berdasarkan analisis tersebut, tim peneliti menyimpulkan bahwa untuk mengatasi kesalahan terjadinya penulisan 
kata yang salah, sebaiknya penulis lebih tekun mempelajari tata bahasa Indonesia, perihal penulisan kata. Kedua, penulis harus peka dan aktif berkonsultasi kepada dosen pengampu mata kuliah perihal penulisan kata yang disalahkan, agar tidak terulang kembali kesalahannya.

\section{Penulisan Tanda Baca}

Terkait penulisan tanda baca, berikut ini kesalahan penulisannya disajikan dalam table di bawah ini,

Tabel A.3 Kesalahan Penulisan Tanda Baca

\begin{tabular}{|c|c|c|c|}
\hline No. & Bentuk-Bentuk Kesalahan & UTS & UAS \\
\hline \multirow[t]{3}{*}{1} & Penggunaan tanda baca yang salah. & & \\
\hline & (1) Titik (.) menjadi koma (,). & $\sqrt{ }$ & $\sqrt{ }$ \\
\hline & (2) Titik (.) menjadi titik dua (:). & $\sqrt{ }$ & \\
\hline \multirow[t]{2}{*}{2.} & Penggunaan tanda baca yang kurang tepat. & & \\
\hline & (1) Apostrof (') menjadi tanda kurung ( ). & $\sqrt{ }$ & \\
\hline \multirow[t]{3}{*}{3.} & Hilangnya tanda baca. & & \\
\hline & (1) Hilangnya tanda titik (.). & $\sqrt{ }$ & \\
\hline & (2) Hilangnya tanda hubung (-). & & $\sqrt{ }$ \\
\hline 4. & Hilangnya tanda baca koma (,) setelah kata sambung. & $\sqrt{ }$ & $\sqrt{ }$ \\
\hline \multirow[t]{3}{*}{5.} & Tidak ada spasi setelah tanda baca. & & \\
\hline & (1) Setelah tanda titik (.). & $\sqrt{ }$ & $\sqrt{ }$ \\
\hline & (2) Setelah tanda koma (,) & $\sqrt{ }$ & $\sqrt{ }$ \\
\hline
\end{tabular}




\section{a. Penggunaan Tanda Baca yang Salah}

Berdasarkan tabel di atas, ada dua tanda baca yang pemakaiannya salah. Pertama adalah tanda koma (,) yang ditempatkan pada gugusan abjad penanda subbab dan gugusan angka sebagai penanda urutan rumusan masalah. Data tersebut yaitu, A, Latar Belakang, B, Rumusan Masalah, 3, Untuk apa..., 2, Mulai umur..., 4, Biasanya berapa... yang ditemukan dalam tugas UTS. Lalu, dalam tugas UAS ditemukan dua data yang masih ada kesalahan yaitu, 1, Mengetabui informasi tentang..., dan 3, mengetahui perbedaan.... Seharusnya, unsur penanda rentetan subbab, urutan rumusan masalah dan tujuan penelitian diawali dengan tanda titik (.), bukan tanda koma. Kedua adalah penggunaan tanda titik dua (:) (2) dalam data C: Tujuan Penelitian yang ditemukan di tugas UTS. Seharusnya, tetap menggunakan tanda titik. Tim peneliti menduga, bahwa kesalahan pemakaian tanda baca ini karena penulis kurang memperhatikan hal-hal sepele dan tidak teliti. Padahal di pelajaran EYD sudah diajarkan.

\section{b. Penggunaan Tanda Baca yang Kurang Tepat}

Berdasarkan tabel di atas, penggunaan tanda baca yang kurang tepat ditemukan pada cara menandai kata yang diterjemahkan. Tanda yang seharusnya dipakai sebagai penanda kata yang diterjemahkan adalah tanda apostrof atau tanda petik tunggal yang mengapit di depan dan di belakang kata yang diterjemahkan. Data yang ditemukan terdapat pada kosakata: seijinshikki (upacara peringatan kedewasaan) yang seharusnya ditulis 'upacara peringatan kedewasaan'. Kedua, kekkoonshiki (pernikahan) yang seharusnya ditulis 'pernikahan'. Ketiga, matsuri ( festifal) yang seharusnya ditulis 'festival'. Tim peneliti menduga, kesalahan ini disebabkan oleh faktor lupa dan kurang teliti terhadap penggunaan tanda baca. Padahal di dalam buku EYD sudah ada keterangan penggunaan tanda apostrof.

\section{c. Hilangnya Tanda Baca}

Pada tabel ke-3, kesalahan penulisan ditemukan pada hilangnya tanda baca titik (.) di akhir kalimat dan tanda hubung (-) untuk menggabungkan unsur Ketuhanan dan bentuk pengulangan kata. Hal ini dapat diamati pada data kalimat yang berbunyi: 1 . Kebiasaan sehari-hari umat Islam di Surabaya, dan 3. Cara mereka berpakaian. Kedua kalimat di atas merupakan kutipan dari tujuan penelitian. Akan tetapi, dalam setiap perinciannya tidak diakhiri dengan tanda titik. Berikutnya, data ditemukan pada penggalan kalimat: ...hamba-hambaNya, ...dengan Undang Undang yang lama. Data kedua ini ditemukan pada tugas UAS. Seharusnya, kata hamba-hambaNya ditulis hamba-hamba-Nya dan kata Undang Undang ditulis dengan menyertakan tanda hubung (), sehingga menjadi Undang-Undang. Tim peneliti beranggapan bahwa kesalahan penulisan kata dengan menghilangkan tanda baca ini juga disebabkan faktor lupa dan tergesa-gesa. Padahal, materi ini sudah ada dalam buku EYD.

\section{d. Hilangnya Tanda Baca Koma (,) setelah Kata Sambung}

Kesalahan keempat dari penulisan tanda baca adalah hilangnya tanda baca koma (,) setelah kata sambung (konjungsi). Data penelitian ini ditemukan dalam penggalan kalimat: Jadi hari itu dosen..., Oleh karena itu kali ini saya..., Oleh karena itu saya paling..., Oleh sebab itu tidak..., Jadi Puasa juga acara yang terkenal di Surabaya, Jadi umat muslim di Surabaya memperhatikan seperti itu. Terhitung ada 7 data yang ditemukan. Seharusnya, setelah konjungsi jadi, oleh karena itu dan oleh sebab itu diakhiri dengan pemarkah koma (,) yang menandakan ada jeda sejenak sebelum memaparkan pernyataan berikutnya. Tim peneliti beranggapan bahwa kesalahan penulisan kata dengan tidak menyertakan tanda baca koma (,) juga disebabkan faktor lupa dan tidak teliti. Padahal, materi ini sudah ada dalam bahasa Indonesia. 
e. Tidak Ada Spasi setelah Tanda Baca

Kesalahan kelima dari penulisan tanda baca adalah tidak dispasinya tanda baca baik berupa titik (.) maupun koma (,) dengan kata yang mengikutinya di depan. Data penelitian berupa tidak adanya spasi setelah tanda titik (.) ditemukan dalam penggalan kalimat:

1. Apa sajakah nama..., 2. Kapan pakaian..., ...belajar tentang agama.Apa saja..., Tetapi Jawa Timur terlalu luas.Oleh Karena itu..., 5.Membuat simpulan. Kedua, data penelitian berupa tidak adanya spasi setelah tanda koma (,) ditemukan dalam penggalan kalimat: (2) ...belajar bahasa Inggris,saya tabu..., Budha,Katholik, Kristen,Islam dan..., (Fitriwandaa,2014:1). Tim peneliti beranggapan bahwa kesalahan penulisan kata dengan tidak menyertakan spasi ini juga dapat disebabkan oleh dua faktor. Pertama, pengaruh penulisan aksara kana dan kanji dalam membuat sakubun 'karangan' yang memang dalam menulisnya tidak perlu dispasi. Faktor kedua, pengaruh setting laptop yang didesai di negara Jepang sendiri, sehingga ketika dibawa ke Indonesia, untuk menyeting model tampilan layar PC seperti di Indonesia agak sulit dilakukan.

Berdasarkan analisis tersebut, tim peneliti menyimpulkan bahwa untuk mengatasi kesalahan terjadinya penulisan tanda baca terulang lagi, sebaiknya penulis membaca kembali buku EYD dan buku bahasa Indonesia, perihal penulisan tanda baca. Kedua, penulis juga harus berinisiatif berkonsultasi kepada dosen pengampu mata kuliah perihal penulisan tanda baca yang disalahkan, agar tidak terulang kembali kesalahannya. Ketiga, segera menyesuaikan setting-an PC ke negara yang dituju agar memudahkan proses pengetikan sebelum mata kuliah "Penulisan Karya Ilmiah" digulirkan.

\section{B. Kesalahan Tata Bahasa}

Perihal kesalahan tata bahasa, berikut ini disajikan hasil analisisnya berupa tabel di bawah ini,

Tabel B. Bentuk-Bentuk Kesalahan Variabel Tata Bahasa

\begin{tabular}{llcl}
\hline No. & \multicolumn{1}{c}{ Bentuk-Bentuk kesalahan } & UTS & UAS \\
\hline 1 & Penggunaan kata yang kurang tepat. & $\sqrt{ }$ & $\sqrt{ }$ \\
\hline 2 & Adanya pemborosan kata. & $\sqrt{ }$ & \\
\hline 3 & Salah menggunakan kata kerja pasif. & $\sqrt{ }$ & $\sqrt{ }$ \\
\hline 4 & Penggunaan kalimat yang kurang tepat. & $\sqrt{ }$ & \\
\hline 5 & Penyusunan kalimat yang kurang tepat. & & $\sqrt{ }$ \\
\hline 6 & Adanya kalimat yang kurang lengkap. & $\sqrt{ }$ & \\
\hline
\end{tabular}


Berdasarkan temuan data, beberapa
bentuk kesalahan yang berhubungan
dengan kesalahan tata bahasa dapat
dikelompokkan menjadi lima kelompok
seperti yang tercantum pada tabel di atas.
Kesalahan tata bahasa terjadi pada saat
mengerjakan tugas uts maupun uas. Contoh
kesalahan tersebut antara lain penggunaan
kata untuk, biasanya, selain itu, seorang, karena yang kurang tepat seperti yang dapat dilihat pada contoh kalimat berikut ini: (1) Mendeskripsikan untuk orang Surabaya naik sepeda motor. Untuk contoh kalimat pertama kesalahan terjadi pada penggunaan kata untuk yang seharusnya menggunakan kata tujuan karena pada kalimat tersebut menjelaskan tujuan penelitian.

Mendeskripsikan biasanya orang Surabaya naik motor. Untuk contoh kalimat kedua pada kata mendeskripsikan seharusnya ditulis dengan kata mendeskripsikan jumlah, karena pada bagian ini juga masih berhubungan dengan tujuan penelitian yang menjelaskan tujuan dari penelitian ini adalah mendeskripsikan jumlah pemakai kendaraan bermotor. (3) Kalau seorang ingin mendapat SIM C untuk.... Selanjutnya, pada kalimat ketiga ada kata seorang. Pada kalimat tersebut kurang tepat karena jika menggunakan kata seorang kalimat tidak jelas, sehingga seharusnya kata seorang diubah menjadi kata seseorang. (4) Selain itu, keduanya dapat pergi.... Untuk contoh kalimat keempat adanya kesalahan penggunaan kata selain itu, yang seharusnya menggunakan walau demikian, karena pada kalimat tersebut sebelumnya menjelaskan tentang kelebihan dan kekurangan naik sepeda motor dan naik mobil, dan keduanya dapat digunakan untuk bepergian dalam jarak yang jauh. (5) Karena saya takut jalan di Surabaya. Kemudian pada contoh kalimat kelima, penggunaan kata karena. Pada kalimat ini tidak perlu menggunakan kata karena yang menjadi menyatakan alasan dari kalimat sebelumnya. Pada kalimat tersebut menyebutkan bahwa mahasiswa tidak dapat naik sepeda motor di Surabaya dan dia takut karena menurutnya orang Surabaya dan sekitarnya tidak mematuhi marka jalan.
Kesalahan lain dalam bentuk pemborosan kata yang terjadi pada saat uts dan uas. Pemborosan kata tersebut merupakan penggunaan kata-kata yang tidak perlu yang tidak seharusnya ada, misalnya kata dari. Pada kalimat mendeskripsikan dari umur orang Indonesia dapat memiliki.... Penggunaan kata dari pada kalimat tersebut, meskipun tidak ada kata dari, tidak akan mengubah arti bahkan ada kata dari pun akan membuat kalimat tersebut menjadi jelas, bahkan sebaliknya sehingga penggunaan kata dari pada kalimat tersebut dianggap sebagai pemborosan kata. Sebagai contoh yang lain pada kalimat mendeskripsikan mulai umur rata-rata orang Surabaya... khususnya pada penggunaan kata mulai karena yang hendak dideskripsikan adalah umur rata-rata orang Surabaya, bukan mulai umur, sehingga kata mulai dianggap sebagai pemborosan kata.

Bentuk kesalahan yang berhubungan dengan penggunaan kata kerja pasif terjadi pada uts saja seperti pada contoh kalimat (1) ...ada banyak orang dipakai bijab... yang seharusnya ..ada banyak orang memakai bijab. Mahasiswa hendak menyampaikan bahwa hijab banyak dipakai oleh orang muslim, sehingga dalam pembetulannya orang muslim memakai hijab. (2) ..hari itu dosen di Unitomo dipakai batik yang seharusnya ..bari itu dosen di Unitomo memakai batik, yaitu batik yang dipakai oleh dosen Unitomo bukan dosen Unitomo dipakai batik sehingga pembetulannya dosen Unitomo memakai batik. Di sini masih terlihat bahwa mahaisswa masih belum memahami penggunaan kata kerja pasif dalam kalimat.

Bentuk kesalahan yang lain antara lain, adanya kalimat yang kurang tepat seperti, pada contoh kalimat berikut: (1) mendeskripsikan biasanya orang Surabaya naik sepeda motor, yang seharusnya mendeskripsikan jumlah orang Surabaya yang biasanya naik sepeda motor. (2) umurnya umum 23 tabun, yang seharusnya umumnya berumur 23 tahun. (3) ketiga, saya memakai angket, yang seharusnya ketiga, saya menyebarluaskan angket. 
Kemudian bentuk kesalahan lainnya adalah penyusunan kalimat yang kurang lengkap. Contohnya antara lain pada kalimat: (1) ..perbedaan antara sepeda motor dan mobil di Osaka dan Surabaya yang seharusnya ..perbedaaan antara sepeda motor di Surabaya, khususnya di Semolowaru dan sekitarnya. (2) ..perbedaan sepeda motor antara di Jepang dan Surabaya yang seharusnya ..perbedaan sepeda motor antara di Surabaya.

Bentuk kesalahan yang lain antara lain, adanya penggunaan kalimat yang kurang lengkap yang terjadi pada saat uas, seperti pada contoh kalimat berikut: (1) ..teman yang sudah pernah hal tersebut, yang seharusnya .. teman yang sudah pernah melakukan bal tersebut. (2) ..tidak selalu dipakai kegiatan sehari-hari. yang seharusnya ..tidak selalu dipakai dalam kegiatan sehari-hari. (3) bijab dipakai wanita muslim, yang seharusnya bijab dipakai oleh wanita muslim.

\section{Kesalahan Sistematika Penulisan}

Seperti yang sudah dijelaskan sebelumnya bahwa data penelitian ini adalah lembar kerja UTS dan UAS dari mata kuliah "Penulisan Karya Ilmiah 1" yang ditulis oleh mahasiswa Universitas Setsunan yang sedang belajar bahasa Indonesia di Fakultas Sastra Universitas Dr. Soetomo. Ada empat lembar kerja UTS dan empat lembar kerja yang menjadi sumber data. Dari data yang terkumpul maka bentuk-bentuk kesalahan yang ditemukan dibagi menjadi dua kelompok seperti pada tabel di bawah ini.

Dua kelompok utama dalam kesalahan sistematika penulisan yang didapat dari data yang dikumpulkan yaitu: cara penulisan dan penulisan pada kalimat. Cara penulisan adalah aturan-aturan yang sudah disepakati oleh pengajar maupun pembelajar untuk keseragaman bentuk penulisan. Aturan ini disampaikan oleh pengajar di awal perkuliahan. Sedangkan kesalahan penulisan kalimat adalah kesalahan pada penggunaan kata sambung, atau kalimat yang tidak dapat dipahami maksudnya.

Tabel C. Kesalahan Sistematika Penulisan

\begin{tabular}{|c|c|c|c|}
\hline No. & Bentuk-Bentuk Kesalahan & UTS & UAS \\
\hline 1 & $\begin{array}{l}\text { Format dan cara penulisan. } \\
\text { 1. Jarak antartulisan di cover. } \\
\text { 2. Tebal-tipis huruf di cover. } \\
\text { 3. Penulisan bab dan subbab. } \\
\text { 4. Penomoran halaman. } \\
\text { 5. Paragraf. } \\
\text { 6. Margin penulisan yang tidak tepat. }\end{array}$ & $\sqrt{ }$ & $\sqrt{ }$ \\
\hline 2 & $\begin{array}{l}\text { Penulisan kalimat. } \\
\text { 1. Koherensi antarkalimat. } \\
\text { 2. Kalimat yang terlalu singkat. } \\
\text { 3. Penjelasan yang tidak mencapai sasaran. }\end{array}$ & $\checkmark$ & $\sqrt{ }$ \\
\hline
\end{tabular}

\section{Bentuk Kesalahan pada Format dan Cara Penulisan}

Kesalahan cara penulisan ditemukan dalam data pada lembar kerja UTS dan UAS sehingga dapat dikatakan pembelajar tidak memahami penjelasan dari pengajar, karena disampaikan pada awal perkuliahan, sehingga ada kemungkinan bahasa yang disampaikan pengajar tidak dapat dipahami secara benar oleh pembelajar, atau mahasiswa kurang teliti dan tidak melihat revisi dari kesalahan yang sudah dilakukan pada saat UTS. Sebagai contoh kesalahan pada tebal tipisnya huruf. Pada saat pengumpulan tugas UTS, dosen mengoreksi kata yang perlu dicetal tebal tetapi tetap ditulis tipis. Kesalahan yang terjadi pada UTS kemungkinan disebabkan 
oleh ketidakpahaman mahasiswa pada penjelasan dosen. Tetapi hal yang sama terulang pada tugas UAS. Hal ini kemungkinan terjadi karena mahasiswa kurang teliti atau pada saat pembuat tugas UAS tidak melihat revisi tugas UTS. Analisis yang sama juga diberlakukan pada kesalahan yang dibuat ketika membuat cover. Mahasiswa tidak memperhatikan jarak antartulisan pada cover.

Pada kesalahan Penulisan Bab dan Subbab, didapati tugas yang tidak mencantumkan kata "BAB I", tidak menuliskan kata "BAB II LANDASAN TEORI" setelah BAB I selesai, atau kata huruf pada bab tidak ditebalkan dan tidak diletakkan di tengah (center), dll. Analisis dari kesalahan ini sama seperti pada paragraf sebelumnya yaitu mahasiswa tidak memahami penjelasan dosen atau mahasiswa kurang teliti dalam menulis.

Kesalahan pada penomoran halaman yaitu ada mahasiswa yang mencantumkan halaman 1 mulai dari cover, daftar isi, isi makalah hingga ke daftar pustaka yang seharusnya cover tidak diberi nomor halaman, penomoran halaman daftar isi ditulis dengan huruf $i$, ii, iii, dst. Penomoran halaman 1, 2, 3, dst dicantumkan pada isi tugas. Kesalahan pada penomoran halaman ditemukan pada data UTS dan UAS. Data UTS telah direvisi tetapi masih ada mahasiswa yang melakukan kesalahan yang sama pada saat UAS. Hal tersebut dapat dikatakan bahwa ketelitian dalam penulisan masih kurang dimiliki oleh mahasiswa.

Ada dua jenis kesalahan yang dilakukan pada penulisan paragraf yaitu kesalahan penulisan awal paragraf yang tidak menjorok ke dalam dan aturan minimal paragraf tidak ditaati. Kesalahan yang pertama, adalah kesalahan dalam hal ketelitian mahasiswa dalam menulis. Sementara ada dua kemungkinan untuk kesalahan kedua yaitu mahasiswa kurang teliti ketika membuat paragraf atau karena kendala bahasa, mahasiswa kurang dapat memberikan penjelasan yang utuh atau kurang dapat mengatur kalimat pada paragraf yang sedang ditulisnya.

Solusi yang dapat diberikan pada kesalahan bentuk penulisan ini adalah dibuatkan sebuah handout dengan bahasa yang sesederhana mungkin yang di dalamnya diberi template penulisan cover dan contoh penulisan daftar isi, contoh penulisan bab dan subbab dan letak penulisan kalimat di awal paragraf, dan penjelasan mengenai cara-cara menuangkan ide dalam sebuah paragraf.

\section{Bentuk Kesalahan pada Penulisan Kalimat}

Kesalahan penulisan kalimat bagi seseorang yang belajar bahasa asing dapat dikatakan suatu kesalahan yang wajar karena konsep bahasa ibu yang ada pada pikiran seseorang seringkali mempengaruhi cara berpikir. Selain itu, keterbatasan kosa kata, tata bahasa, ungkapan juga menjadi kendala untuk dapat mengekspresikan pendapat dengan baik. Kendala keterbatasan yang dimiliki membuat maksud pemikiran pembicara tidak dapat ditangkap oleh lawan bicara.

Ada tiga jenis kesalahan pada penulisan kalimat yang berhasil ditemukan yakni koherensi antarkalimat, kalimat yang terlalu singkat, dan penjelasan yang tidak mencapai sasaran. Kesalahan penulisan yang mengakibatkan koherensi antarkalimat tidak tersambung dengan baik yaitu tidak digunakannya kata sambung atau salah pada penggunaan kata sambung. Salah satu contoh kesalahan penulisan yang ditemukan adalah "Kali ini saya mengambil Madura, Malang, dan Sidoarjo". Dalam hal ini penulis mencantumkan nama-nama kota tetapi tidak dijelaskan akan dibagaimanakan data tersebut. Pembetulan dari kesalahan tersebut adalah "Penulis mengambil data baju tradisional yang berasal dari daerah Madura, Malang, dan Sidoarjo."

\section{SIMPULAN}

Berdasarkan hasil analisis, simpulan penelitian ini adalah (1) Faktor kesalahan pemahaman dan penulisan karya ilmiah 
mahasiswa Setsunan angkatan ke-13 semester gasal tahun akademik 2017/2018 disebabkan oleh tiga faktor utama, yaitu: (a) kesalahan penulisan ejaan yang terdiri atas kesalahan penulisan huruf kapital, kecil dan huruf miring, kesalahan penulisan kata serta kesalahan penggunaan tanda baca, (b) kesalahan tata bahasa berbentuk penggunaan kata yang kurang tepat dan boros, kesalahan menggunakan kata kerja pasif, penggunaan kalimat yang kurang tepat dan kurang lengkap, serta penyusunan kalimat yang kurang tepat, (c) kesalahan sistematika penulisan yang terdiri atas kesalahan format dan cara penulisan serta kesalahan penulisan kalimat, dan (2) Cara mengatasi kesalahan dalam pemahaman dan penulisan karya ilmiah agar tidak terjadi kesalahan yang terus berulang dapat dilakukan dengan upaya konkret di antaranya: (1) membuat modul Pengajaran Penulisan Karya Ilmiah I dengan bahasa yang sederhana, lengkap dengan isi yang mencakup: (a) sistematika penulisan dan penjelasannya, (b) format penulisan dan penjelasannya, (c) ilustrasi penulisan kata, tata bahasa dan paragraf yang benar, (d) trik pengembangan ide menjadi tulisan yang koheren, (e) silustrasi gambar agar membuat mahasiswa tidak bosan, dan (2) membuat RPS yang tersistem untuk pengajaran satu semester.

\section{DAFTAR RUJUKAN}

Alwi, H., Dardjowidjojo, S., Lapoliwa, H., \& Moeliono, A.M. (2003). Tata Bahasa Baku Indonesia. Jakarta: Balai Pustaka.

Azizah, R.F., et al. (2012). Pembelajaran bahasa Indonesia bagi penutur asing (BIPA) program CLS (critical language scholarship) di Fakultas Sastra Universitas Negeri Malang tahun 2012. Diakses pada tanggal 24 nopember 2017 dari: http://jurnalonline.um.ac.id/data/artikel.

Djajasudarma, F. (2010). Metode Linguistik. Bandung: Refika Aditama.

Keraf, G. (2010). Diksi dan Gaya Bahasa. Jakarta: Gramedia Pustaka Utama.
Moleong, L.J. (2017). Metode Penelitian Kualitatif. Edisi Revisi. Bandung: Remaja Rosdakarya.

Siagian, E.N. (2017). Analisis Kesalahan Berbahasa (Tulis) Mahasiswa BIPA Tingkat Lanjut Universitas Yale, USA. Makalah. Diakses dari:http://jurnal.unej.ac.id/index.ph p./fkip-article/download.

Pusat Bahasa Kemdiknas Republik Indonesia. (2012). Pedoman Umum Ejaan Babasa Indonesia Yang Disempurnakan dan Pedoman Umum Pembentukan Istilah. Bandung: Pustaka Setia.

Sudaryanto. (2016). Cerdas Menulis Karya Ilmiah. Yogyakarta: Sanata Dharma University Press 